\title{
飛騨山脈・白馬岳北部地域の地すべり地形発達
}

\author{
佐 藤 剛* 菏谷 愛 彦*

\section{Geomorphological Development Caused by Landslides in the Northern Area of Mt. Shiroumadake, the Hida Mountains, Japan}

Go SATO* and Yoshihiko KARIYA*

\begin{abstract}
This paper describes the Holocene development of landslides in the northern area of Mt. Shiroumadake in the Hida Mountains of central Japan. Late Quaternary landforms caused by glaciers or landslides are common in the study area, where previous studies have provided basic information on glacial landforms with only few details on landslides. This study classifies landslide topography into three types: I, II, and III, based on air photo interpretation and field investigation, to reveal morphological characteristics.

Type I comprises up-hill facing scarps or linear depressions without a deforming landslide body. However both type II and type III have a visible landslide body. Only type III features frontal debris accumulation. Type I is distributed almost throught the study area. Type II and type III are distributed on slopes underlain mainly by serpentinite and stratified rocks comprising of shale, sandstone, felsic tuff, and tuff breccia. Gravitational rock creep and resulting rock deformation seem to be important in the formation of type I and type II. Type I landslide seems to be transformed into type II landslide with rock deformation on the slopes in the order: (1) gravitational creep, (2) deformation with a discontinuous slip surface, and (3) slide with a continuous slip surface. Radiocarbon dating and tephrostratigraphical evidence reveal that landslide activities began in the early Holocene epoch, and have continued until the present.
\end{abstract}

Key words : landslide, geomorphic development, Holocene epoch, the Hida mountains キーワード：地すべり, 地形発達, 完新世, 飛騨山脈

\section{I.はじめに}

飛騨山脈北部の白馬岳 $(2,932 \mathrm{~m})$ 周辺は, 詳 細な水河地形・地質研究がなされた日本でも数 少ない場所の 1 つである。とくに白馬岳東面の 北股入では多数の堆石が発見され, ${ }^{14} \mathrm{C}$ 年代や指 標テフラとの層序が明らかにされた（小疇ほか,
1974; 伊藤 ・清水, 1987; 荻谷, 2000)。また白馬 岳北面を流域に含む大所川上流部（白高地沢・瀬 戸川流域）でも堆石が見つかり，北股入との対 比が試みられた（小疇・岡沢, 1976, 1977; 五百 沢, 1979)。最近ではそれらの ${ }^{14} \mathrm{C}$ 年代や指標テ フラとの層序も報告されている（苅谷, 2000）。 一方, 本地域では氷河地形・堆積物ばかりでな

* 千葉大学大学院自然科学研究科

* Graduate School of Science and Technology, Chiba University 
く，地すべり地形・堆積物が発達するとの指摘も ある(石井, 1998; 防災科学技術研究所, 2000; 中 野ほか, 2002)。地すべり地形・堆積物の発達は, 本地域に地すべりを誘発しやすいとされる苦鉄質 岩体や堆積岩類が分布し, 日本有数の多雪環境が 成立していることが関係していると考えられる。

最新水期以降, 飛騨山脈では完新世初期までに 温暖化が進み水河はほぼ消滅した ${ }^{1)}$ 。同時期，中 部日本の日本海側では多雪化も生じたと見られる (Sakaguchi, 1978)。しかし最新水期以降の飛騨 山脈の地形形成過程は，まだ十分理解されていな い。飛騨山脈の山地地形学を構築するには, 水河 地形・堆積物やそれらの周辺に発達する周氷河地 形・堆積物ばかりでなく, 地すべり地形・堆積物 の正確な識別を基礎とする分布・年代の解明, 古 環境復元が要件にあげられる。

筆者らは, 白馬岳北部地域に分布する地すべり 地形の空中写真判読と現地調查を行った。その結 果をもとに, 地すべり地形の形態・分布とそれら から推定される運動様式, 地すべり発達過程およ び地すべりの年代新資料を論述する。

\section{II. 調 查 地}

\section{1）範囲}

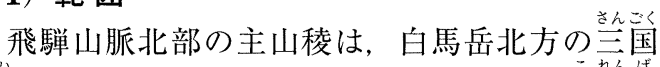
境で北東・北北西方向に分岐する。前者は示蓮華 山や白馬大池を経て, 蓮華温泉に至る。後者は雪 倉岳や朝日岳を経て, 長栂山に至る（図 1)。

本研究では, この 2 つ主稜線を主な分水界と する姫川水系白高地沢および瀬戸川のほほ全流域 と, 朝日岳の北に位置する黒部川水系患振谷と南 に位置するゼンマイ谷および赤男谷の最上流部を 調查対象とした（図 1)。朝日岳東面を源流とす る白高地沢 (流域面積 $8.2 \mathrm{~km}^{2}$ ) は, 標高 $1,430 \mathrm{~m}$ 地点で赤男沢を合わせ, 同 $1,015 \mathrm{~m}$ 地点で瀬戸 川と合流する。また三国境北面を源流とする瀬戸 川（流域面積 $17.1 \mathrm{~km}^{2}$ ) は白高地沢との合流後, 標高 $970 \mathrm{~m}$ 地点で矢兵衛川を迎え, 大所川とな る。

\section{2) 地形}

調查地では複数の水河地形・堆積物の存在が指

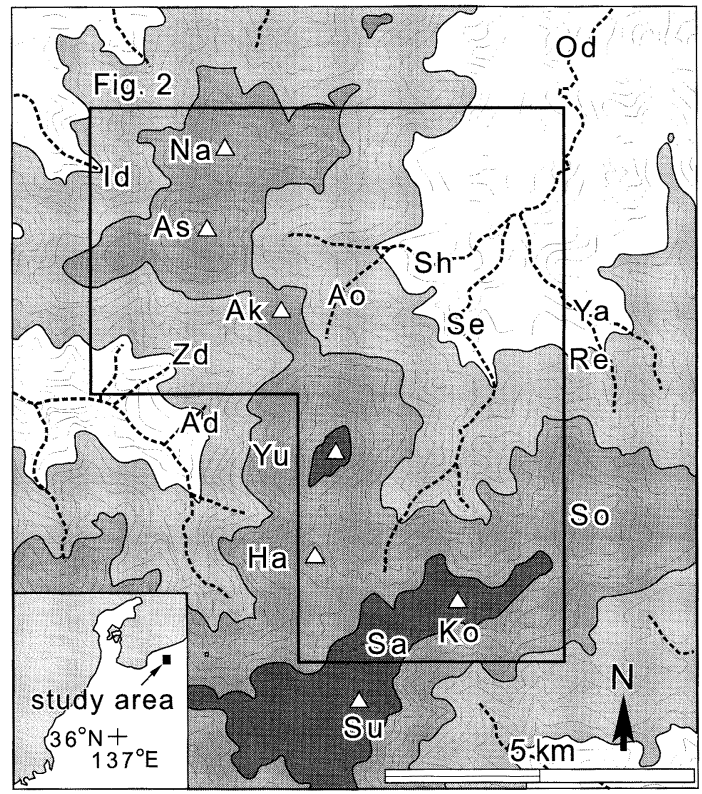

$\geqq 2,500 \mathrm{~m}$ asl. $\geqq 2,000 \mathrm{~m}$ asl.

$\square \geqq 1,500 \mathrm{~m}$ asl. ....... river $\triangle$ summit

図 1 調查地の位置と周辺の地形.

$\mathrm{Su}$ : 白馬岳 $(2,932 \mathrm{~m}), \mathrm{Ko}_{\mathrm{o}}$ : 小蓮華山 $(2,769 \mathrm{~m})$, $\mathrm{Ha}$ : 鉢ヶ岳 $(2,563 \mathrm{~m}), \mathrm{Yu}$ : 雪倉岳 $(2,611 \mathrm{~m})$, $\mathrm{Ak}$ : 赤男山 $(2,910 \mathrm{~m}), \mathrm{As}$ : 朝日岳 $(2,418 \mathrm{~m})$, $\mathrm{Na}$ : 長栂山 $(2,267 \mathrm{~m}), \mathrm{Sh}$ : 白高地沢, $\mathrm{Se}:$ 瀬戸川, Ao：赤男沢, Ya：弥兵衛川, Od：大所川, Id : 恵 振谷, $\mathrm{Zd}$ : ゼンマイ谷, $\mathrm{Ad}$ : 赤男谷, $\mathrm{Sa}$ : 三国境, So : 白馬大池, Re : 蓮華温泉. 等高線の間隔は $100 \mathrm{~m}$.

Fig. 1 Location and topography of the study area. $\mathrm{Su}$ : Shiroumadake $(2,932 \mathrm{~m})$, Ko: Korengesan $(2,769 \mathrm{~m}), \mathrm{Ha}$ : Hachigadake $(2,563 \mathrm{~m})$, Yu: Yukikuradake $(2,611 \mathrm{~m})$, Ak: Akaotokoyama (2,910 m), As: Asahidake $(2,418 \mathrm{~m}), \mathrm{Na}$ : Nagatsugayama $(2,267 \mathrm{~m})$, Sh: Shirakochisawa R., Se: Setogawa R., Ao: Akaotokosawa R., Ya: Yaheigawa R., Od: Odokorogawa R., Id: Iburidan R., Zd: Zenmaidan R., Ad: Akaotokodan R., Sa: Sangokuzakai, So:Lake Shirouma-oike, Re: Renge spa. Contour interval is $100 \mathrm{~m}$.

摘されている。小疇・岡沢（1976）は端堆石位 置を古い順に標高約 $800 \mathrm{~m}$, 約 $1,200 \mathrm{~m}$ および 約 $1,500 \mathrm{~m}$ とし, 3 回の水河前進を推定した。近 ごろ, これら氷河地形・堆積物の ${ }^{14} \mathrm{C}$ 年代や広域 テフラとの層序が報じられ，新たな解釈も示され た（石井, 1998; 荻谷, 2000)。

調査地の主稜線付近には周水河性平滑斜面と 
残雪凹地が分布する（Iwata, 1983; 黒田ほか, 2001)。前者は積雪の多い主稜線西側に, 後者 は積雪の少ない東側に主に発達する。いずれも 現成の地形は少なく, 大半が晚水期以前（

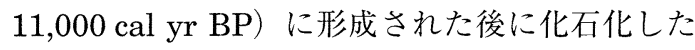
と推定されるが, 完新世に一部が再生した（黒田 ほか, 2001)。

\section{3）地質}

飛騨山脈北部は飛騨外縁帯からなり, 地質構造 は複雑である。調査地は主に時代未詳の蛇紋岩化 した超苦鉄質岩（以下，蛇紋岩とよぶ）, ペルム 系の古生層および第三紀に貫入した珪長岩からな り, 一部にデボン紀 - 石炭紀の変成岩, 鮮新世の 花崗閃緑岩および中期更新世の安山岩質溶岩が存 在する（図 2A：原山ほか, 1995）。

蛇紋岩は剪断変形を受けてレンズ状に破砕さ れていることが多く（中野ほか, 2002），葉片状・ 粘土状を呈することもある。また角閃岩や古生 界の岩塊を含み（中野ほか, 2002), 蛇紋岩メラ ンジュをなす。古生層は珪長質凝灰岩・凝兏角硽 岩, 頁岩および砂岩頁岩互層からなる白馬岳層 （中野ほか, 2002）を主体とする。珪長岩は蛇紋 岩と古生層に貫入している（中野ほか, 2002）。

\section{4) 気候}

気候は多雪・多雨に特徵づけられる。雪が吹き だまりやすい主稜線東側の斜面では, 積雪深が数 $\mathrm{m}$ 以上に達するところもある。また谷底の周囲 では, 雪崩で集積した雪が初秋まで残ることがあ る。近接する長野県白馬村と新潟県糸魚川市のア メダス観測資料（1979-2000年）から, 調査地 の年平均気温は $2.4^{\circ} \mathrm{C}$, 年降水量は約 $2,300 \mathrm{~mm}$ 以上と推定される ${ }^{2)}$ 。

\section{III. 方 法}

\section{1）地すべり地形学図の作成}

空中写真 (国土地理院撮影, 縮尺約 $1: 15,000$, C CB-76) 判読と野外調査資料から地すべり地形 学図（図 $2 \mathrm{~B}$ )を作成した ${ }^{3)}$ 。

\section{2）年代資料の収集 $\left({ }^{14} \mathbf{C}\right.$ 年代・テフラ $)$}

地すべり地形の露頭や試坑で堆積物を記載し, テフラ試料と ${ }^{14} \mathrm{C}$ 年代測定試料（木片）を採取し
た。テフラ試料は屋内で洗浄・乾燥後, 顕微鏡観 察を行うとともに，試料に含まれる火山ガラス片 35 粒以上の屈折率測定をした ${ }^{4)} 。{ }^{14} \mathrm{C}$ 年代測定は Beta Analytic 社に委託した。同位体分別補正済 み ${ }^{14} \mathrm{C}$ 年代 ${ }^{14} \mathrm{C}$ yr BP) は IntCal 98（Stuiver et al., 1998）を組み込んだ OxCal 3.9 （Bronk Ramsey, 2003）により暦年に較正した（cal yr $\mathrm{BP} ; 2 \sigma)$ 。

\section{IV. 結 果}

\section{1）地すべり地形の地形学的特徵と分布}

形態的な特徵から, 調査地に分布する地すべり 地形を 3 つのタイプ $(\mathrm{I} 〜 \mathbb{I I})$ に分類した。

\section{〈タイプI〉}

稜線付近から斜面中腹にかけて等高線とほほ 平行に伸びる線状凹地（linear depression; 松 岡, 1985）や尾根向き低崖（uphill-facing scarp: Radbruch-Hall, 1978）である。これらの地形自 体は，滑落崖および移動体をもつ典型的な地す心゙ り地形ではない。しかし後述するように，線状凹 地や尾根向き低崖は, 主として重力性岩盤クリー プによる山体変形で生じた正断層に由来すると 考えられ, 先行研究 (Varnes, 1978; Dramis and Sorriso-Valvo, 1994）でもマスムーブメントを表 わす地形の一種に分類されている。

タイプIは長栂山や朝日岳南面, 雪倉岳一鉢ヶ 岳一三国境を結ぶ主稜線沿いに分布する（図 $2 \mathrm{~B}$ )。 例えば, 長栂山周辺には主稜線に平行な北東-南 西方向の線状凹地と低崖列が発達する。とくに長 栂山山頂東側直下の線状凹地は長さが約 $670 \mathrm{~m}$, 開口部の幅は約 $170 \mathrm{~m}$, 凹地底と凹地の東側に 位置する尾根向き低崖頂部との比高は最大 $10 \mathrm{~m}$ あり, 周囲にも尾根向き低崖が発達する。

赤男山西面の標高 $2,140 \mathrm{~m}$ 付近にも北西-南東 方向に伸びる尾根向き低崖が分布する。この尾根 向き低崖の周辺には, 空中写真判読では確認可能 だが図 $2 \mathrm{~B}$ には表現できない比高 1-2 $\mathrm{m}$ 程度の低 崖が数列分布している。地点 $\mathrm{P} 1$ ではこれらの低 崖が分布する斜面の一部が崩壊しており，内部構 造を露頭で確認することができる（図 $3 \mathrm{~A}$ ）。基盤 (珪長岩) は節理が発達し, 断層で切られている。 


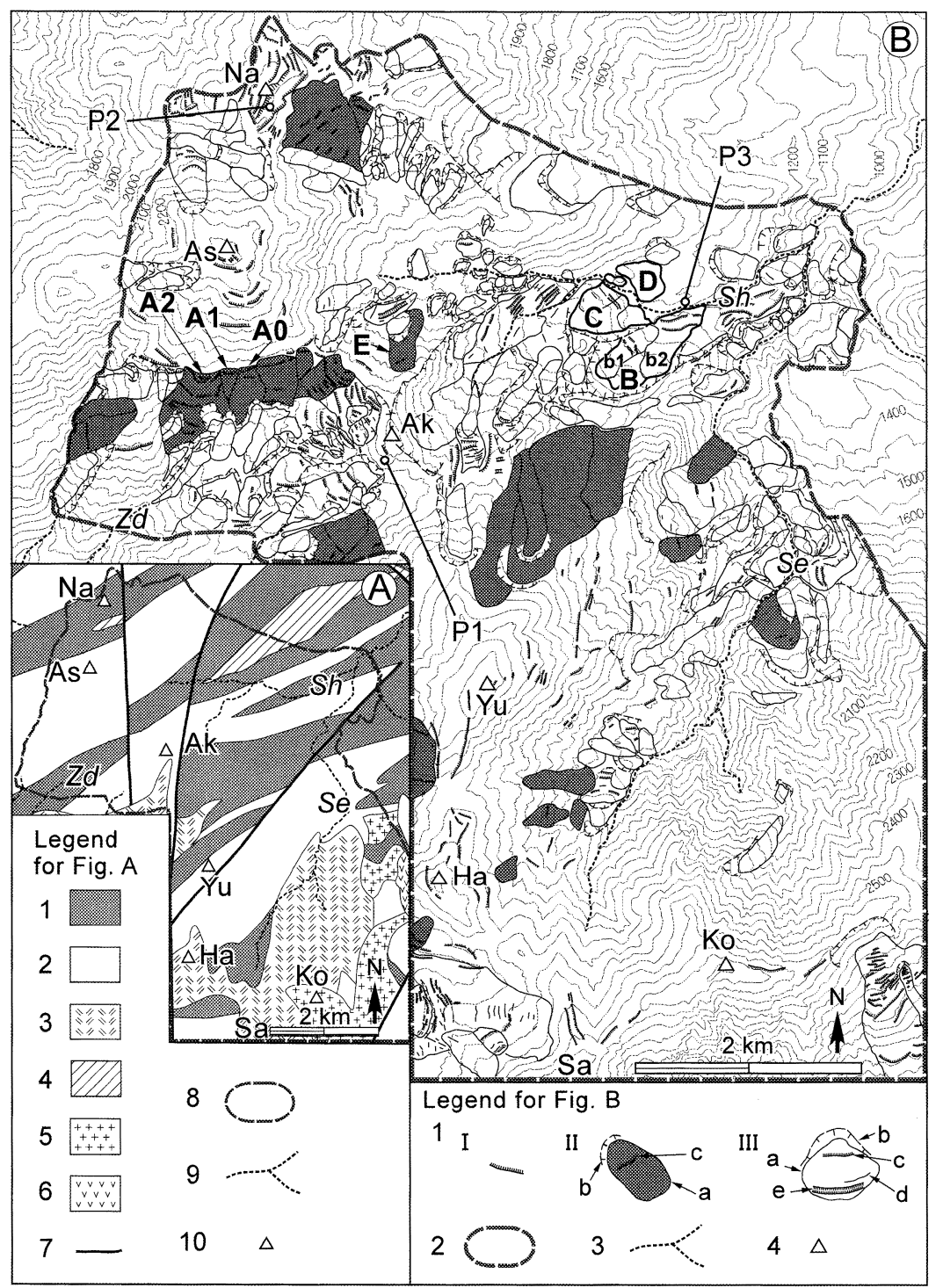

図 2 地質図 (A) および地すべり地形学図 (B).

A） 1. 蛇紋岩, 2. 古生層, 3. 珪長岩, 4. 変成岩, 5. 花崗閃緑岩, 6. 安山岩溶岩, 7. 断層, 8. 調查範囲, 9. 河川, 10. 山頂. (原山ほか, 1995 を改変)

B） 1. 地すべり地形（I：タイプI，II：タイプII，III：タイプIII, a : 地すべり移動体, b : 滑落崖, $\mathrm{c}$ ：尾根向き低崖, $\mathrm{d}$ : 幅の狭い線状凹地, e : 幅の広い線状凹地), 2. 調査範囲, 3. 河川, 4. 山頂. 等高線間隔は $50 \mathrm{~m}$.

$\mathrm{Na}$ ：長栂山, $\mathrm{As}$ ：朝日岳, $\mathrm{Ak}$ ：赤男山, $\mathrm{Yu}$ ：雪倉岳, $\mathrm{Ha}$ ：鉢ヶ岳, $\mathrm{Ko}$ ：小蓮華山, $\mathrm{Sh}$ ： 白高地沢, Se : 瀬戸川, Zd : ゼンマイ谷, $\mathrm{Sa}$ ：三国境.

Fig. 2 Geological map (A) and landslide map (B).

A) 1. serpentinite, 2. Paleozoic strata, 3. felsite, 4. metamorphic rocks, 5. granodiorite, 6. lava, 7. fault, 8. investigated area, 9. river, 10. summit. (Modified from Harayama et al., 1995).

B) 1. landslide (I: type I, II: type II, III: type III, a: landslide body, b: main scarp, c: up-hill facing scarp, $\mathrm{d}$ : narrow linear depression, $\mathrm{e}$ : wide linear depression), 2. investigated area, 3. river, 4. summit. Contour interval is $50 \mathrm{~m}$.

$\mathrm{Na}$ : Nagatsugayama, As: Asahidake, Ak: Akaotokoyama, Yu: Yukikuradake, Ha: Hachigadake, Ko: Korengesan, Sh: Shirakochisawa R., Se: Setogawa R., Zd: Zenmaidan R, Sa: Sangokuzakai. 
また，断層を境に谷側の基盤は山側に比べ著しく 破砕されている。断層面の走向・傾斜は $\mathrm{N} 37^{\circ} \mathrm{W}$ $47^{\circ} \mathrm{W}$ である。断層面には条線が発達し, 断層面 沿いには粘土に充填される断層角鿬が約 $20 \mathrm{~cm}$ の厚さで認められる（図 3B）。

〈タイプII 〉

移動体の輪郭が識別できる地すべり地形であ る。一般に地すべり地形は発生域および移送・堆 積域（大八木, 1992）に分かれるが, タイプIIの 移動体の大部分は発生域のもので, 移送・堆積域 がほとんど識別できない。この点で次述するタイ プIII と異なる。移動体と上方の非変動斜面との境 界に滑落崖が生じていることはまれである。移動 体全体の傾斜もタイプIIIり急である。ただし移 動体上面に 1 数列の尾根向き低崖が分布する ことがあり，そのような部位は傾斜が緩い。移動 体上面のこれらの尾根向き低崖には移動体内部に 分布が限られる短いものと, 等高線方向に伸張し て移動体側方の他の移動体上または非変動斜面上 の尾根向き低崖によく続くものとがある。なお, タイプII の移動体上の尾根向き低崖はタイプ I と 形態が似るが，タイプII の移動体を形成させた地 すべり活動の影響を受けていると考えられること から同タイプの地形構成要素の一部として扱う。

タイプII は朝日岳南面や長栂山東面, 雪倉岳北 面に分布する（図 $2 \mathrm{~B}$ )。朝日岳南面に分布する移 動体 $\mathrm{A} 0$ （長さ $540 \mathrm{~m}$, 幅 $270 \mathrm{~m}$ ）では, 移動体 上半部に 2 列の尾根向き低崖が発達する。下側 のもの（長さ $80 \mathrm{~m}$, 比高約 $20 \mathrm{~m}$ ) はこの移動体 内に分布が限られる。上側のもの（長さ $130 \mathrm{~m}$, 比高約 $8 \mathrm{~m}$ ) は移動体 $\mathrm{A} 0$ と上方の非移動斜面の 境界付近に位置する。上側の尾根向き低崖は等高 線に沿った側方への連続性がよく, 移動体の西に 存在する移動体 $\mathrm{A} 1$ 最上部の尾根向き低崖に断続 的につながる。移動体 $\mathrm{A} 1$ の西側にはさらに移動 体 $\mathrm{A} 2$ が存在し, 移動体 $\mathrm{A} 2$ 最上部に見られる尾 根向き低崖は北西側の非変動斜面上の尾根向き低 崖（タイプI）に断続的に連続する。同様に, 移 動体A 0 の東側の移動体上にも断続的に尾根向 き低崖が分布する。

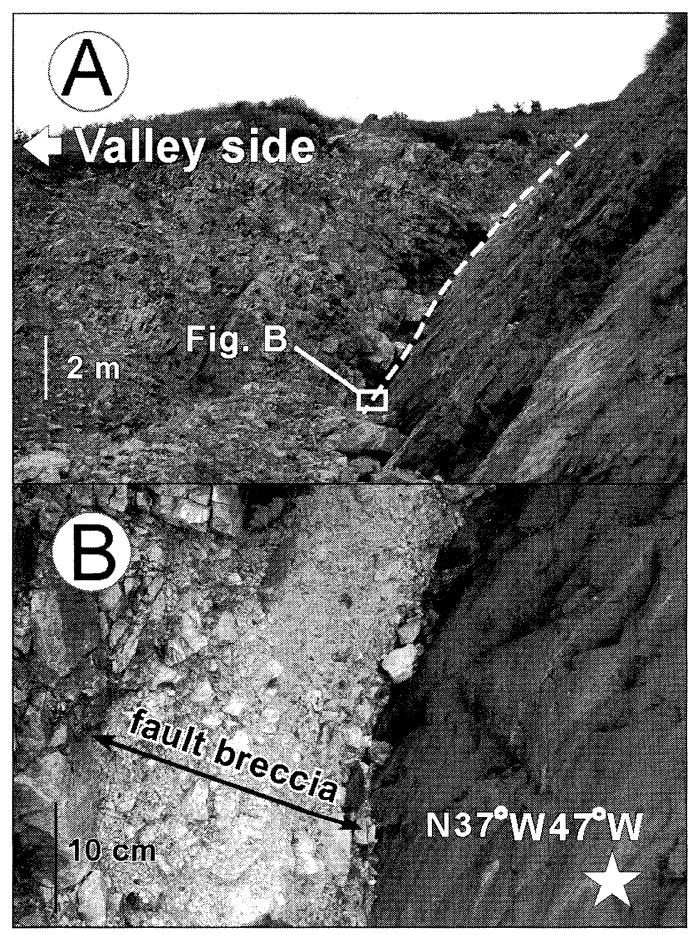

図 3 A）タイプIの内部構造. 破線は断層を示す. B) 断層面.

Fig. 3 A) Internal structure of Type I landslide. Dashed line shows fault.

B) Fault plane.

〈タイプIII〉

移動体の輪郭が識別でき, かつ移動体が発生域 と移送・堆積域に分類できる地すべり地形であ る。また，移動体内に二次的な地すべり活動にと もない形成された移動体が分布することもある。 二次的なものも含め, 移動体の傾斜は夕イプII り緩い。移動体の上方には明瞭な遷急線をもつ滑 落崖が見られることが多い。

タイプIIIは白高地沢右岸のほぼ全域や，ゼンマ イ谷上部の赤男山西面, 瀬戸川流域下流部で発達 がよい（図 $2 B ） 。$ 白高地沢下流部右岸には標高 $1,700 \mathrm{~m}$ 付近に比高約 $90 \mathrm{~m}$ の馬蹄形の滑落崖を 伴う長さ $920 \mathrm{~m}$, 幅 $490 \mathrm{~m}$ の移動体 B が存在す る。移動体中には二次的な地すべりで生じた移動 体 b1 および b2 が形成されている。これらの移 動体上には推定移動方向に直交する線状山地も生 
じている ${ }^{5)}$ 。図 $2 \mathrm{~B}$ に示していないが，移動体 b2 の下端では白高地沢の側刻・下刻による表層崩壊 が現在も生じている。移動体 b2 の二次的活動の 主因は白高地沢の侵食によると考えられる。同様 の事例は，この地すべり地形の北西隣にも見られ (移動体 C), 白高地沢の側刻により移動体末端の 開析が進んでいる。移動体 C の北東側には, 白 高地沢を挟んで移動体 D が分布するが, 移動体 $\mathrm{C}$ と D はもともと一連の地すべり移動体であっ たと考えられる。その理由として, 左岸側谷壁斜 面には移動体 Dの発生源となった地形が見られ ないこと, また移動体 C と D は岩相が同一な破 砕・粘土化した蛇紋岩で構成されていることがあ ゲられる。

\section{2）地すべり地形の分布と地質}

タイプ I は三国境周辺や小蓮華山北面などの珪 長岩地域では主稜線付近に分布が限られるのに対 し, 朝日岳や雪倉岳周辺の蛇紋岩地域および古生 層地域では主稜線付近から斜面中腹にかけて分布 する（図 2)。またタイプ II と同 III は白高地沢流 域やゼンマイ谷上部, 瀬戸川下流域などの蛇紋岩 地域および古生層地域に多く分布し, 珪長岩地域 では分布が限定的である。

\section{3）年代資料}

長栂山山頂付近には最新水期ないし晚水期に形 成されたと考えられる化石周水河性平滑斜面が分 布し，これを切って線状凹地が発達する。線状凹 地底にある地点 $\mathrm{P} 2$ （図 2B）では，凹地を埋積す る泥炭と腐植まじりシルトの互層が地表から深度 $20 \mathrm{~cm}$ まで観察され, 深度 $18.5 \mathrm{~cm}$ 付近には褐色 のシルト質粘土がパッチ状に挟在する。この粘土 は，ほほ全量が平板状泡壁型火山ガラス片（屈折 率 $\mathrm{n}=1.503-1.512 ）$ からなる。それらの多くは 無色透明だが, 淡褐色のものも検出される。こう した特徴や周辺域での産状からこの火山ガラ ス片は鬼界アカホヤ（K-Ah; 7,300 cal yr BP : 町 田・新井, 2003）に同定される。

白高地沢左岸の地点 P3（図 2B）では, 現河床 に高さ約 $10 \mathrm{~m}$ の破砕された閃緑岩が露出し, こ れを層厚 $50 \mathrm{~m}$ 以上の砂磁層が覆う（図 4)。閃 緑岩は破砕しており，同質の閃緑岩は右岸側の移

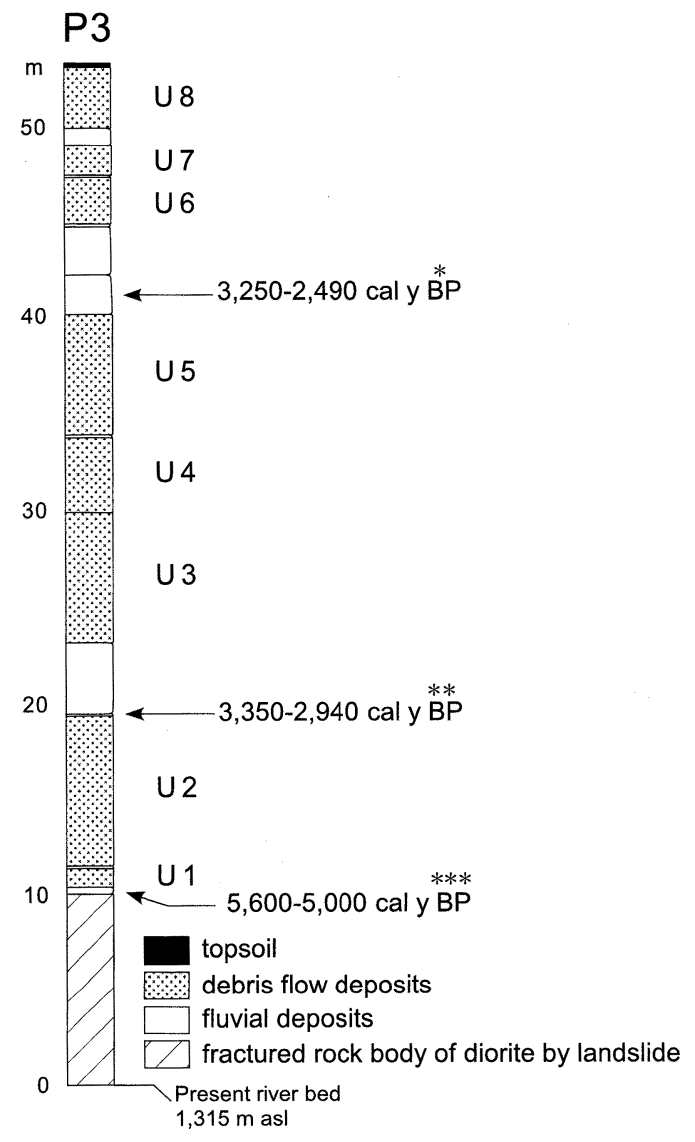

図 4 土石流および河成堆積物柱状図. 露頭位置は図 $2 \mathrm{~B}$ に示す. U1 8: 土石流堆積物 のユニット。*石井 $(1998)$ および苅谷 $(2000)$ のデー 夕を用いた。 ${ }^{* *}$ Beta-186406. ${ }^{* * * B}$ Beta-182346. 較 正年代はいずれも $2 \sigma$.

Fig. 4 Columnar section of debris flow and fluvial deposits at Loc. P3.

Location is shown in Fig. 2B. U1-8: debris flow unit. * This age was arranged by Ishii (1998) and Kariya (2000). ${ }^{* *}$ Beta-186406. ${ }^{* * *}$ Beta-182346. Calibrated ${ }^{14} \mathrm{C}$ years are indicated with a $2 \sigma$ confidence level

動体 B（b2）の末端部にも露出する。砂碟層は 河川堆積物と土石流堆積物との互層で構成され る。淘汰がよく層状・覆瓦構造を呈する河川堆積 物に対し, 土石流堆積物は不淘汰で粘土から長軸 の長さが $3 \mathrm{~m}$ を越える礫で構成される。本層上 部に挟在する泥炭の ${ }^{14} \mathrm{C}$ 年代測定が行われ $3,250-$ 2,490 cal yr BP が得られている（石井, 1998; 荻 
谷, 2000)。土石流堆積物のユニット 1 に覆われ る河成堆積物，およびユニット 2 とその直上の 河成堆積物の境界部から新たに得た木片は, そ れぞれ 5,600-5,000 cal $\left(4,600 \pm 90{ }^{14} \mathrm{C}\right)$ yr BP と 3,350-2,940 cal $\left(2,970 \pm 70{ }^{14} \mathrm{C}\right)$ yr BPだっ た。砂礫層は堆石丘状の地形をなすことから氷河 堆積物の可能性が指摘されていた（小疇・岡沢， 1976, 1977）が，完新世の土石流堆積物を主体と していることが明らかになった。

\section{V. 議 論}

\section{1）地すべりの運動形式}

現時点では移動体の内部構造に関する情報がそ しく, 地すべりの運動様式や発達過程を確定する ことはできない。以下では, タイプ I 〜 II の地形 や分布の特徵から，これらを予察的に論じる。

タイプ I の尾根向き低崖が分布する赤男山西面 （図 $2 \mathrm{~B}$ ，地点 $\mathrm{P} 1$ ）では，前述のように斜面内部 に断層が見られる。この断層は断層面が谷側に傾 斜していることから, 谷側の基盤が落ちた正断層 である。断層と尾根向き低崖列との構造的な関係 は判明していない。しかし，尾根向き低崖は断層 の走向とほぼ同方向に伸びていることから，その 形成には断層活動が影響したと予想される。

従来から線状凹地や尾根向き低崖は, 大比高の 主稜線周辺に発達することが知られており，それ らは重力性岩盤クリープに伴う山体变形で生じる と考えられてきた（Dikau et al., 1996）。例えば 清水ほか (1980) は, 山地の隆起と河川の下刻 によって山体が自重で側方へ膨らみ, 山稜部が引 張場となって低崖（正断層）が形成されると推 定した。清水ほか（1980）は明言していないが, 山体の膨らみは重力性岩盤クリープに因むと考 えられる。またChigira（1992）やChigira and Kiho（1994）は，急斜する面構造をもつ岩盤が トップリングを起こした斜面と，その上方に位置 する非変動斜面との境界部が引張場におかれ，低 崖（正断層）が生じると考えた。この場合，トッ プリングは重力性岩盤クリープによるとされる。

こうしたことから，タイプIは重力性岩盤ク リープに由来する正断層で形成された可能性が高
(6)。

タイプ II の移動体上には 2 種類の尾根向き低崖 が存在する。このうち, 移動体と隣り合う別の移 動体や非変動斜面上の尾根向き低崖と断続的に分 布するものは，本来ほほ同標高に存在した一連の 低崖だったと考えられる。典型例が見られる朝日 岳南面（図 2B）の場合, かつて斜面の広い範囲 で重力性岩盤クリープが生じ, 尾根向き低崖（夕 イプ I ）が出現したが, 斜面の一部で変動が促さ れ明瞭な移動体（タイプ II）が形成されることで 一連の低崖は分断されたと推定される。一方，赤 男山北面の移動体 E に分布する尾根向き低崖の ように，その分布が移動体上に限られ，周囲の非 変動域に等高線方向へ連続しないものは, 当該移 動体の変形だけで生じたと考えられる。

岩盤クリープに伴う岩盤の変形・破壊が進む と, 斜面内部に断層が生じ, さらに斜面横断・縦 断方向に連続する剪断面（すべり面）が形成され る（千木良, 1995）。この結果，すべり面を境に 岩盤が滑動しはじめ, 斜面上には輪郭が識別可能 な移動体が生じる。以上が夕イプ I から同 II のの 発展過程と推定される。

タイプIII滑落崖を伴い, 移動体には移送・堆 積域も形成されている。海外では，岩盤クリープ が進行してスライド (slide: Varnes, 1978）や岩屑 なだれ（debris avalanche: Varnes, 1978）などの崩 壊現象に至ることが知られている（Nemčok, 1972; Radbruch-Hall, 1978; Dramis and SorrisoValvo, 1994)。

以上をまとめると調查地の地すべりは，始めに 岩盤クリープに伴うタイプIの形成，次にすべり 面の形成に伴うタイプ II の形成，さらに地すべり 活動が進み夕イプIII の形成へと遷移する発達過程 があると考えられる。

\section{2）地すべり地形の分布と地質}

タイプIは, 珪長岩地域と蛇紋岩地域・古生層 地域とでは斜面上の出現位置に違いがある。

本地域の珪長岩は節理の発達がよく，崩れやす い。また珪長岩が分布する瀬戸川右岸一帯は主稜 線と谷底の比高が大きく, 周水河性平滑斜面の発 達がよい主稜線付近を除いて谷壁の傾斜も全般に 
急である。これに対し，蛇紋岩や古生層が分布す る瀬戸川左岸一帯や白高地沢流域では主稜線と谷 底の比高が相対的に小さく，谷壁の傾斜も緩い。 珪長岩地域では重力性岩盤クリープが作用して斜 面上に正断層が形成される状況となっても, 斜面 が急なため移動体は速やかに崩壊してしまい, 尾 根向き低崖や線状凹地（タイプI）が残存しない。 逆に化石周水河斜面の発達の結果, 比較的傾斜が 緩い珪長岩地域の主稜線付近では崩壊による斜面 変動が起こりにくく, タイプI の存続が可能であ る。

タイプ II およびIII は蛇紋岩・古生層地域に集中 し, 珪長岩地域にはほとんど見られない。上述の ように, 珪長岩地域ではタイプ I から同 II に発展 する地形・地質的素因に欠けていることがその理 由と考えられる。また調査地の蛇紋岩や古生層は 構造運動を受け脆弱化しており, 蛇紋岩は粘土化 していることも多い。蛇紋岩地域では異種岩体と の境界部や断層面沿いに地すべりが発生しやす い(横田ほか, 1995, 1998; 矢田部ほか, 1997; 佐々 木ほか, 2001)。また, 古生層の多くは珪質凝灰 岩・凝灰角磁岩と砂岩頁岩互層からなる。凝灰岩 は粘土化しすべり面へと転化することや（西山 ほか, 2003), 砂岩頁岩互層では層理面を境にす ベり面が形成されることが知られている（藤田, 2002)。

調查地の蛇紋岩や古生層分布域にタイプ II や III が広く分布するのは, 蛇紋岩や古生層の地質的特 性を反映していると考えられる。

\section{3）地すべり発生時期}

地点 $\mathrm{P} 2$ （図 2B）がある線状凹地は, 主稜線 周辺の化石周水河性平滑斜面を切っていることか ら, 形成期が晚水期以前に遡る可能性は低い7)。 また地点 $\mathrm{P} 2$ における埋積土壤と K-Ahの発見は, この線状凹地（タイプ I ）が 7,300 cal yr BP 以 前に生じたことを示す。

地点 P3（図 2B）に扔ける露頭観察の結果, 全 層厚 $43 \mathrm{~m}$ 以上の砂礫層が 1,750-3,110 年間にわ たり白高地沢を埋積したことが明らかとなった。 これほどの埋積が生じた過程として, 露頭近傍で の地すべり活動と, それに続く上流からの土砂供
給が推定される。その理由として, 露頭最下部に 右岸側の移動体 B 末端に露出する閃緑岩と同質 なものが認められることがある。つまり，右岸側 で発生した地すべりが 5,600-5,000 cal yr BP 以 前に白高地沢を塞き止め堆積場を形成した。それ を契機とし, 計 8 ユニットの土石流堆積物に代 表される上流から供給された多量の堆積物が白高 地沢を埋積した。

地すべりによる塞き止めの事例は地点 P3 の上 流でも認められる。移動体 $\mathrm{C}$ および移動体 D は 同一の岩相を有する蛇紋岩で構成されることか ら, 両移動体は右岸側で発生した地すべりの一連 の移動体である。つまり, 地すべり活動にともな い移動体が左岸谷壁斜面基部まで達し, 白高地沢 を塞き止めた。その後, 移動体は白高地沢に開 析され, 移動体 C と移動体 D に分割された。移 動体 D は, 地点 $\mathrm{P} 3$ の砂礫層からなる地形面を 覆うことから, 一時的な白高地沢の塞き止めが 3,250-2,490 cal yr BP 以後にもあった。

また，タイプ II や同 IIIの移動体上には形態が明 瞭な尾根向き低崖や線状凹地が形成され, 現在ま たは近過去まで地すべりが進行してきたことを示 唆する。

これらの事例は, 調査地で完新世を通じて地す べりによる活発な地形変化が生じてきたことを示 している。

\section{VI. むすび}

調查地やその周辺に最新水期に氷河が存在して いたことは確実（五百沢, 1979）である。しかし, 遅くとも完新世前半以降には夕イプ I から同 III 発展する地すべり地形の発達が進んだ。地すべり 活動の誘因として以下のプロセスが想定される。

最新水期に氷河作用が及んだ斜面の一部では, 氷河により斜面に与えていた荷重が退水後に解放 され，地すべり活動が発生したと予想される。退 氷に伴う内部応力の変化のために不安定化した水 食谷壁では, 尾根部周辺や斜面上に重力性岩盤ク リープによる線状凹地や尾根向き低崖が形成され る paraglacial rock-slope deformation の事例が 多数報告されている（Ballantyne, 2002）。 
一方, 退水以外に多雨・多雪化による地下水供 給量の増加や, 河川の下刻による斜面不安定化 （中村・檜垣, 1991）などの発生要因もあげられ る。また尾根向き低崖が地震動によって累積的に 発達する例も報告されている（八木浩司, 1993）。 調査地が日本有数の多雪地域にあり, しかも数千 年間隔で活動してきた糸魚川-静岡構造線活断層 系神城断層とその北方延長部 (奥村ほか, 1998; 中野ほか, 2002）に近接することから, 融雪水や 地震動が発生要因となっていることも予想され る。

飛騨山脈の地形発達を解明するためには, 地す べりの発生誘因や構造地質学的な運動様式の解 明，そして詳細な編年が今後重要である。

\section{謝 辞}

古谷尊彦・宮内崇裕両先生 (千葉大学), 石井正樹 氏 (北陽建設), 目代邦康博士 (筑波大学) には貴重な 助言をいただいた。また，八木令子博士 (千葉県立中 央博物館), 吉村章彦氏 (元千葉大学大学院生), 加藤 暁之氏 (千葉大学学生) には分析や現地調査に協力い ただいた。さらに, 若名査読者・担当委員には的確な コメントをいただいた。記して感謝します。研究の一 部に日本科学協会平成 16 年度笹川研究助成金(代表者： 佐藤 剛), 河川環境管理財団平成 14 年度研究助成金 および平成 14 年度千葉大学大学院自然科学研究科共同 研究助成（代表者：苅谷愛彦）を使用した。

\section{注}

1）朝日岳北面では完新世前半に氷河が形成された可能 性がある (小疇・岡沢, 1983).

2) 気温減率を $6.5^{\circ} \mathrm{C} \mathrm{km}$-1 とし, 調查地の平均高度 $(1,800 \mathrm{~m})$ の年平均気温を 2 地点の観測值から別々 に求め, それらを相加平均した。年降水量も 2 地点 の観測值の相加平均とした。

3）写真判読は佐藤と苅谷が独立に行い, 双方の結果を 照査した。

4）千葉県立中央博物館所有の京都フィッション・ト ラック RIMS86 を用いて佐藤が測定した。

5）タイプIIIの移動体上の線状凹地は, クラックおよび 溝状凹地（木全・宮城, 1985; 八木令子, 2003）に対 応する地形であり, タイプI とは区別した。

6）本稿でタイプI とした地形の一部を相馬（1974）と 上本（1978）が言及している，ただし彼らは線状凹 地が広域的地殼变動に支配されて生じたとし, 岩盤 クリープに起因する正断層起源である可能性は論じ ていない.
7）上本 (1978) や高山地形研究グループ (1978) も 本地域の線状凹地が最新水期を遡らないとした．根 拠として, 線状凹地底堆積物が薄いことや, それら が含有する花粉化石組成に現在との間に有意な差が ないこと, 線状凹地が現成または近過去の周水河性 斜面物質を切ることなどがあげられた。

\section{文献}

Ballantyne, C.K. (2002): Paraglacial geomorphology. Quat. Sci. Rev., 21, 1935-2017.

防災科学技術研究所 (2000): 地すべり地形分布図 第 11 集「富山・高山」. 防災科学技術研究所資料, 第 200 号.

Bronk Ramsey, C. (2003): OxCAL program v3.9, [http://www.rlaha.ox.ac.uk/oxcal/oxcal.htm].

Chigira, M. (1992): Long-term gravitational deformation of rocks by mass rock creep. Eng. Geol., 32, 157-184.

Chigira, M. and Kiho, K. (1994): Deep-seated rockslide-avalanches preceded by mass rock creep of sedimentary rocks in the Akaishi Mountains, central Japan. Eng. Geol., 38, 221-230.

千木良雅弘 (1995): 風化と崩壞. 近未来社.

Dikau, R., Brunsden, D., Schrott, L. and Ibsen, M. eds. (1996): Landslide recognition: Identification, Movement and Causes. Wiley \& Sons.

Dramis, F. and Sorriso-Valvo, M. (1994): Deep-seated gravitational slope deformations, related landslides and tectonics. Eng. Geol., 38, 231-243.

藤田 崇 (2002): 地すべりと地質学. 藤田 崇編：地す べりと地質学. 古今書院, 3-21.

原山 智 - 滝沢文教 - 加藤碵一 - 駒澤正夫 - 広島俊男 須藤定久 (1995): 20 万分の 1 地質図幅「富山」. 地 質調查所.

五百沢智也 (1979): 鳥㒈図譜 $=$ 日本アルプス。講談社.

石井正樹 (1998): 大所川流域の地すべり地形と発達史. 日本地理学会発表要旨集, 53, 110-111.

伊藤真人・清水文健 (1987): 北アルプス, 白馬岳東方, 松川北股入のモレーンを覆う示標テフラ層の発見と その意義. 地学雑誌, 96, 112-120.

Iwata, S. (1983): Physiographic conditions for the rubble slope formation on Mt. Shirouma-dake, the Japan Alps. Geogr. Rep. Tokyo Metropol. Univ., 18, $1-52$.

苅谷愛彦 $(2000)$ : 白馬岳地域に扔ける更新-完新統の年 代新資料. 日本地理学会発表要旨集， 58，68-69.

木全令子・宮城豊彦 (1985): 地すべり地を構成する基 本単位地形. 地すべり, $21(4), 1-9$.

小疇 尚・岡沢修一 (1976): 白馬岳北方, 大所川流域の 氷河堆積物と地形. 日本地理学会予稿集, 10, 2526.

小疇 尚 - 岡沢修一 (1977): 白馬 - 朝日連峰東斜面の水 河地形. 日本地理学会予稿集, 12, 20-21.

小疇 尚 - 岡沢修一 (1983): 後立山連峰北部, 朝日岳の 完新世プッシュモレーン。 日本第四紀学会講演要旨 集, 13，110-111.

小疇 尚・杉原重夫 · 清水文健 - 宇都宮陽二朗 - 岩田修 
二・岡沢修一 (1974) : 白馬岳の地形学的研究. 駿台 史学, 35, 01-086.

高山地形研究グループ (1978): 白馬岳高山帯の地形と 植生. 163.

黒田真二郎・岩田修二・苅谷愛彦 (2001): 表層堆積物 の断面構造から推定した白馬岳高山帯における周水 河砂磁斜面の形態変化. 日本地理学会発表要旨集, 59, 92 .

町田 洋・新井房夫 (2003): 新編火山灰アトラス [日本 列島とその周辺]. 東京大学出版会.

松岡憲知 (1985): 赤石山脈主稜線部における線状凹地 の分布と岩石物性. 地理学評論, 58A，411-427.

中村三郎・檜垣大助 (1991): 地すべり地形の生成と変 化. 地すべり学会シンポジウム「地すべり災害斜面 のうつりかわりと地下水排除・効果」論文集, 6876.

中野 俊 - 竹内 誠 - 吉川敏之・長森英明 - 苅谷愛彦 奥村晃史. 田口雄作 (2002): 白馬岳地域の地質. 地 域地質研究報告 (5万分の 1 地質図幅). 産総研地質 調査総合センター, 105.

Nemčok, A. (1972): Gravitational slope deformation in high mountains. Proc. 24th Int. Geol. Congr., Sect. 13, 132-141.

西山勝一・松本一一 - 山田 清 (2003): 佐賀県峰池地 すべりのすべり面. 日本地すべり学会誌, $40(4)$, 90-91.

奥村晃史 - 井村隆介 - 今泉俊文 - 東郷正美 - 澤 祥 水野清秀・茠谷愛彦 - 斉藤英二 (1998): 糸魚川-静岡 構造線活断層系北部の最近の断層活動. 地震, $\mathbf{5 0}$, 別冊, 35-51.

大八木規夫 (1992): 土砂災害. 萩原幸男編 : 災害の事 典. 朝倉書店, 179-252.

Radbruch-Hall, D.H. (1978): Gravitational creep of rock masses on slopes. In Voight, B. ed.: Rockslide and Avalanches, 1. Elsevier, 607-657.

Sakaguchi, Y. (1978): Climatic changes in central Japan since 38,400 y BP - viewed from palynologi- cal study on Ozegahara deposits. Bull. Dept. Geogr., Univ. Tokyo, 10, 1-10.

佐々木慶三・中村真也 - 周 亜明 - 宜保清一 (2001): 姫川メランジェの大規模地すべりの発生機構につい ての検討. 地すべり， 37(4)，24-32.

清水文健・東郷正美・松田時彦 (1980): 日本アルプ ス・野口五郎岳付近に打ける小崖地形の成因. 地理 学評論, 53, 531-541.

相馬秀広 (1974): 白馬岳北部におけるいわゆる “二重 山稜”。 日本地理学会予稿集, 6, 104-105.

Stuiver, M., Reimer, P.J., Bard, E., Beck, J.W., Burr, G.S., Highen, K.A., Kromer, B., McCormac, G., Van Der Plicht, J. and Spurk, M. (1998): INTCAL98 radiocarbon age calibration, $24,000-0$ cal BP. $R a-$ diocarbon, 40, 1041-1083.

上本進二 (1978): 白馬岳北方鉢岳西斜面の新期断層地 形. 第四紀研究， 17，171-175.

Varnes, D.J. (1978): Slope movement types and processes. In Schuster, R.L. and Krizek, R.J. eds.: Landslides: Analysis and Control. Natl. Acad. Sci. Spec. Rep., 176, 11-33.

八木浩司 (1993): 真昼山地・和賀岳付近に認められる 小崖地形の発達過程. 季刊地理学, 45, 83-91.

八木令子 (2003): 地すべり移動体の微地形構成とその 配列パターン：地すべり地形の発達過程解析手法と しての地形分類の意義. 地形, 24, 261-294.

矢田部龍一・横田公忠・八木則男 - 野地正保 (1997): 蛇紋岩地すべりの発生機構に対する検討. 地すべり, 34(1)，24-30.

横田公忠 - 矢田部龍一 一八木則男 (1995): 蛇紋岩の風 化粘性土の強度特性. 土木学会論文集, 529, 155163.

横田公忠 - 矢田部龍一・八木則男 (1998): 蛇紋岩地す べりに対する鉱物学的一考察. 地すべり, $\mathbf{3 5}(3)$, 15-23.

(2004 年 6 月 9 日受付, 2005 年 1 月 21 日受理) 